\title{
Fabrication and Identification of the Efficiency of a Si-Based Solar Cell
}

\author{
Mohammad Mahmuduzzaman Tawhid ${ }^{1}$, Omar Faruk Rasel ${ }^{1, ~ *}$, Mahbubul Hoq ${ }^{2}$, Nasrul Haque ${ }^{2}$ \\ ${ }^{1}$ Department of Physics, Khulna University, Khulna, Bangladesh \\ ${ }^{2}$ Institute of Electronics, Bangladesh Atomic Energy Commission, Dhaka, Bangladesh
}

Email address:

Ku.tawhid@gmail.com (M. M. Tawhid)

*Corresponding author

\section{To cite this article:}

Mohammad Mahmuduzzaman Tawhid, Omar Faruk Rasel, Mahbubul Hoq, Nasrul Haque. Fabrication and Identification of the Efficiency of a Si-Based Solar Cell. Industrial Engineering. Vol. 2, No. 1, 2018, pp. 12-18. doi: 10.11648/j.ie.20180201.12

Received: September 17, 2018; Accepted: September 28, 2018; Published: October 23, 2018

\begin{abstract}
This research represents the fabrication and characterization of a solar cell which is based on a thin p-type silicon (Si) wafer. Solar cells are the basic building blocks of Solar Panels or Modules. There are presently nine companies manufacturing solar modules in the country. Nowadays a large amount of electricity comes from solar cell. The total demand for solar cells in assembling solar modules of the nine companies are about 80-90MWp annually. Mainly, cost of solar cell depends on the Brand, type of crystal structure (Mono or Multi) and the shape or size of wafer. For the first time in the country, 'Bangladesh Atomic Energy Commission (BAEC)' has set up a laboratory to fabricate crystalline solar cells on a pilot basis. The method used to fabricate solar cells is the low-cost diffusion technique using $\mathrm{POCl}_{3}$ gas source. Several solar cells of $150 \times 150$ $\mathrm{mm}^{2}$ sizes and 200 micrometer thick are produced and characterized in the laboratory. A p-type silicon wafer is cleaned and textured to make its surface pyramid shape for absorbing more sunlight. The p-n junction used in Si-based solar cell is created after applying diffusion technique using Phosphorus-oxy-try chloride $\left(\mathrm{POCl}_{3}\right)$ within the silicon wafer and putting Aluminum (Al) paste on one side of the wafer. Perfectly texturing ensures the excellent pyramid height of the silicon wafers. The pyramid heights of raw, textured and doped wafers are 8233.2 $\AA, 15222.5 \AA$ and $55654.1 \AA$ respectively. The pyramid surface shows the increasing light absorption by the solar cell that can lead to an increase in conversion efficiency of the device. The efficiency of the produced solar cell is 3.3\%. The results have shown that some challenges and good opportunities in getting the high-efficient and cost effective solar cells. If the cost effective technology can be made familiar in Bangladesh then it will help in solving the power crisis in the country a great deal.
\end{abstract}

Keywords: $\mathrm{POCl}_{3}$, Efficiency, Texturing, Solar Cell Fabrication, Silicon Wafer, Diffusion Technique

\section{Introduction}

The photovoltaic (PV) effect was first observed by Alexandre-Edmond Becquerel in 1839. Subsequently, in 1946 the first modern solar cell made of silicon was invented by Russel Ohl [1]. The growing demand for energy and the increasing threat of global warming due to massive $\mathrm{CO}_{2}$ emission are tremendous future challenges for mankind [2]. The market-share of thin-film never reached more than 20 percent in the last two decades and has been declining in recent years to about 9 percent of worldwide photovoltaic production in 2013 [3]. Several energy storage devices are available in the market but those are highly expensive and a short life span. In 2014, Harvard University researchers developed a new type of battery based on organic molecules called Quinone. It is found in plants and is economical in a sense that it can store sunlight energy for a couple of days [4]. In 2016, 93\% of the global PV cell manufacturing capacity utilizes crystalline silicon $(\mathrm{cSi})$ technology, representing a commanding lead over rival forms of PV technology, such as cadmium telluride (CdTe), amorphous silicon (aSi), and copper indium gallium selenide (CIGS). Nowadays, due to the de-creasing amount of renewable energy resources, the per watt cost of solar energy device has become more important in the last decade, and is definitely set to become economical in the coming years and grow as better technology in terms of both cost and applications [5]. In 2016, manufacturers in China and Taiwan met the majority of global PV module 
demand, accounting for $68 \%$ of all modules, followed by the rest of Asia at 14\%. The United States and Canada manufactured $6 \%$, and Europe manufactured a mere 4\% [6]. The solar cell technology is going to become a key approach for future energy resources [7]. Silicon is the most important material for high efficient photovoltaic solar cell which is the most promising method for directly converting photons to electricity [8]. Photons of energy, hv equal or higher than the band gap, $\mathrm{E}_{\mathrm{g}}$ can be absorbed by the silicon and thereby excite electrons from the valence band to the conduction band creating electron-hole pairs. Then the build-in electric field contributes to separation of the electrons and the holes, which otherwise would recombine, and thus electrical energy is created. The silicon wafers absorb large amount of light due to better improvement of textured surface morphology (e.g. pyramid size, distribution, etc.) [9-10]. The advantages of CIGS thin film solar cells include its prolonged life without a considerable de-gradation. These properties of CIGS indicate an easy solution to enhance the efficiency [11]. Perovskites are a class of compounds defined by the formula $\mathrm{ABX} 3$ where $\mathrm{X}$ represents a halogen such as $\mathrm{I}-, \mathrm{Br}-, \mathrm{Cl}^{-}$. and $\mathrm{A}$ and $\mathrm{B}$ are cations of different size. Perovskite solar cells are recent discovery among the solar cell research community and possess several advantages over conventional silicon and thin film based solar cells. Conventional Si based solar cells need expensive, multiple processing steps and require high temperatures $\left(>1000^{\circ} \mathrm{C}\right)$ and vacuums facilities [12]. The perovskites based solar cells can have efficiency up to $31 \%$ [13]. The converging of the sunlight radiations thus produces a large amount of heat energy. This heat energy is further driven by a heat engine controlled by a power generator with integrated. CPVs have shown their promising nature in solar world [14]. Therefore, the conversion efficiencies can be improved by increasing pyramid size of textured cell structure. Besides, diffusion process is used to produce pn-junction into the silicon wafer and built-in electric fields within the wafer. When a photon of sufficient energy impinges on the p-type and n-type junction, an electron is ejected by gaining energy from the striking photon and moves from one layer to another. This creates an electron and a hole in the process and by this process electrical power is generated. [15] The cell efficiency automatically falls at PV module level. Currently, the efficiencies of commercial PV modules vary in the range of $3 \%-8 \%$. They can be easily operated at elevated temperatures, and are suitable for the changing climatic conditions where sun shines for few hours [16]. The purpose of this research is to fabricate solar cell using texturing and diffusion processes with mono crystalline p-type silicon wafer which acts as a light absorber due to its shape of roughness to produce electricity.

\section{Materials and Methods}

The mono crystalline silicon wafer was used for fabricating the solar cell in our research. This experiment was performed by using four point probe system. The starting material was p-type silicon wafer. The weight and average thickness of the raw silicon wafer were $6.47 \mathrm{gm}$ and 182.5 $\mu \mathrm{m}$ respectively and the crystal orientation was (100). This experimental precedures are explained sequentially below:

\subsection{Cleaning Process}

For cleaning at first 4 litre Deionised(di) water and $400 \mathrm{gm}$ $\mathrm{NaOH}$ were provided in a beaker to make $10 \% \mathrm{NaOH}$ solution. Then the solution was heated till the temperature became $70^{\circ} \mathrm{C}$. After that the wafer tray was put into the beaker and was removed from the beaker after $10 \mathrm{~min}$. Moreover, in order to make the wafers hydrophobic $80 \mathrm{ml}$ $\mathrm{HF}$ (Hydrofluoric acid) and 4 litre di water $\left(\mathrm{HF}: \mathrm{H}_{2} \mathrm{O}=1: 50\right)$ was taken in another cleaned beaker. Then the wafers were dipped into the solution for $3 \mathrm{~min}$. Afterward the wafers were dried with compressed gas.

\subsection{Texturing Process}

For texturing, 4 litre di water and 32 gm $\mathrm{KOH}$ were taken in another cleaned beaker and heated it till the temperature became $70^{\circ} \mathrm{C}$. Then the solution of $160 \mathrm{ml}$ Iso-propanol-2 and the wafers were put into the beaker simultaneously. After $10 \mathrm{~min}$ the wafers were removed and put into di water for 3 min. Then the wafers were dried by compressed gas. This process transformed the crystal orientation to (111) from (100) and consequently the wafer surface could absorb more sunlight than before.

\subsection{Edge Isolation Process}

For edge isolation process Screen Printing Machine and diffusion barrier paste were used. After completing edge isolation the wafers were put into a preheated oven at $200^{\circ} \mathrm{C}$ for $10 \mathrm{~min}$.

\subsection{Diffusion Process}

In diffusion process, the technology used for the doping method was phosphorus diffusion from Phosphorus Oxy-Chloride. Initially the p-type mono-crystalline silicon wafer of having weight $5.37 \mathrm{gm}$ and average thickness of $163.75 \mu \mathrm{m}$ turning on the diffusion chamber of the diffusion machine with centre zone temperature set to $600^{\circ} \mathrm{C}$. Then nitrogen gas was turned on and waited for 10 minutes. Then temperature was increased to $875^{\circ} \mathrm{C}$ keeping the nitrogen gas on. After reaching temperature $875^{\circ} \mathrm{C}$, nitrogen gas was turned off and oxygen $\& \mathrm{POCl}_{3}$ were turned on simultaneously and after 10 minutes of diffusion time oxygen and $\mathrm{POCl}_{3}$ gas were turned off simultaneously and nitrogen gas was turned on and was to allow the nitrogen gas flow for 10 minutes. After 10 minutes nitrogen gas was turned off and only oxygen gas was turned on for the next 10 minutes. After that oxygen gas was turned off and nitrogen gas was allowed to flow for another 10 minutes. Finally after 10 minutes the temperature of the chamber reduced to $600^{\circ} \mathrm{C}$ from $875^{\circ} \mathrm{C}$ and during this stage nitrogen gas was kept turned on. Once the temperature of the chamber was dropped to $600^{\circ} \mathrm{C}$, the nitrogen gas was turned off and the wafers were ready to take out. 


\subsection{Back Front Contact Printing}

The Silver (Ag) and Aluminum (Al) paste were applied on the mask's front and back contact respectively and the wafers were placed in a preheated oven at $200^{\circ} \mathrm{C}$ for 10 minutes. This concluded the screen printing process for the wafers. Then the wafers were passed through a moving belt at temperatures of $500^{\circ} \mathrm{C}, 600^{\circ} \mathrm{C}$ and $800^{\circ} \mathrm{C}$ respectively using rapid thermal annealing (RTA).

\section{Results and Discussion}

From the Dektak images, it can be found the comparison of the surfaces among the raw, textured and doped wafers and the sharpness of surfaces such as pyramid shapes were increasing gradually which improves the absorption efficiency in order to improve efficiency of solar cell. The pyramid height of the raw silicon wafer was $8233.2 \AA$. After performing texturing, the pyramid shape was gradually increasing to $15222.5 \AA$. Again after doping the weight was increased $0.14 \mathrm{gm}$, thickness was $163.75 \mu \mathrm{m}$ in an average and bulk resistivity was $2.82 \Omega \mathrm{cm}$. The surface was still in pyramid shape. A solar cell with a p-type silicon wafer was fabricated using pyramid shaped silicon wafer by phosphorus diffusion method and the major characterization equipment, Light-Current-Voltage (LIV) tester which gives the energy conversion efficiency by using open circuit voltage $\left(\mathrm{V}_{\mathrm{oc}}\right)$, short circuit current $\left(\mathrm{I}_{\mathrm{sc}}\right)$ and Fill Factor $(\mathrm{FF})$.

Table 1 shows the description of raw and cleaned wafers and Table 2 shows the properties of textured and doped wafers. Initially the weight, average thickness and average resistivity of the raw wafers were $6.47 \mathrm{gm}, 182.5 \mu \mathrm{m}$ and $4.22 \Omega \mathrm{cm}$ respectively.

Table 1. Properties of raw and cleaned silicon wafers.

\begin{tabular}{|c|c|c|c|c|c|c|c|c|}
\hline \multirow[b]{2}{*}{ Weight } & \multicolumn{4}{|l|}{ Raw Wafer } & \multicolumn{4}{|c|}{ Cleaned Wafer } \\
\hline & $6.47 \mathrm{gm}$ & & & & $\begin{array}{l}5.65 \mathrm{gm} \\
\text { Weight los }\end{array}$ & $(6.47-5.65)$ & $0.82 \mathrm{~g}$ & \\
\hline Thickness & $180 \mu \mathrm{m}$ & $190 \mu \mathrm{m}$ & $185 \mu \mathrm{m}$ & $175 \mu \mathrm{m}$ & $174 \mu \mathrm{m}$ & $167 \mu \mathrm{m}$ & $180 \mu \mathrm{m}$ & $157 \mu \mathrm{m}$ \\
\hline Average thickness & $182.5 \mu \mathrm{m}$ & & & & $\begin{array}{l}169.5 \mu \mathrm{m} \\
\text { Thickness }\end{array}$ & $(182.5-16$ & $\mu \mathrm{m}=13 \mu \mathrm{m}$ & \\
\hline $\begin{array}{l}\text { Bulk resistivity } \\
\text { Average resistivity }\end{array}$ & $\begin{array}{l}5.28 \Omega \mathrm{cm} \\
4.22 \Omega \mathrm{cm}\end{array}$ & $4.21 \Omega \mathrm{cm}$ & $4.23 \Omega \mathrm{cm}$ & $3.33 \Omega \mathrm{cm}$ & $\begin{array}{l}2.38 \Omega \mathrm{cm} \\
3.1 \Omega \mathrm{cm}\end{array}$ & $3.68 \Omega \mathrm{cm}$ & $2.30 \Omega \mathrm{cm}$ & $3.14 \Omega \mathrm{cm}$ \\
\hline
\end{tabular}

Table 2. Properties of text ured and doped silicon wafers

\begin{tabular}{|c|c|c|c|c|c|c|c|}
\hline \multirow{3}{*}{ Weight } & \multicolumn{3}{|l|}{ Textured Wafer } & \multicolumn{4}{|c|}{ Doped Wafer } \\
\hline & \multicolumn{3}{|l|}{$5.28 \mathrm{gm}$} & \multicolumn{4}{|l|}{$5.37 \mathrm{gm}$} \\
\hline & \multicolumn{3}{|c|}{ Weight loss $=(6.47-5.28) \mathrm{gm}=1.19 \mathrm{gm}$} & \multicolumn{4}{|c|}{ Weight increased: $(5.42-5.28) \mathrm{gm}=0.14 \mathrm{gm}$} \\
\hline Thickness & $158 \mu \mathrm{m}$ & $166 \mu \mathrm{m}$ & $153 \mu \mathrm{m}$ & $162 \mu \mathrm{m}$ & $163 \mu \mathrm{m}$ & $174 \mu \mathrm{m}$ & $156 \mu \mathrm{m}$ \\
\hline \multirow{2}{*}{ Average thickness } & $160 \mu \mathrm{m}$ & & & $163.75 \mu \mathrm{m}$ & & & \\
\hline & \multicolumn{3}{|c|}{ Thickness loss: $(182.5-160) \mu \mathrm{m}=22.5 \mu \mathrm{m}$} & \multicolumn{4}{|c|}{ Thickness loss: $(182.5-163.75) \mu \mathrm{m}=18.75 \mu \mathrm{m}$} \\
\hline Bulk resistivity & $3.98 \Omega \mathrm{cm}$ & $2.90 \Omega \mathrm{cm}$ & $2.39 \Omega \mathrm{cm}$ & $3.12 \Omega \mathrm{cm}$ & $3.32 \Omega \mathrm{cm}$ & $2.65 \Omega \mathrm{cm}$ & $2.22 \Omega \mathrm{cm}$ \\
\hline Average resistivity & $2.97 \Omega \mathrm{cm}$ & & & $2.82 \Omega \mathrm{cm}$ & & & \\
\hline
\end{tabular}

After completing the cleaning process, the weight of the cleaned wafer was reduced to $5.65 \mathrm{gm}$ as well as average thickness and the average resistivity followed the same process showing the roughness which is the most important parameter for absorbing sunlight and this quality also improves after completing the doping processes.

From Figure 1, Figure $2 \&$ Figure 3, it was observed the surface roughness of the raw, textured and doped wafers respectively. The up-down lines indicated the roughness of the surface. The RED (R) straight line indicates the REFERENCE line from where we started our measurement of the distance and the GREEN (M) line indicates MEASUREMENT line where we ended our measurement of distance. The distances were taken horizontally $360.7 \mu \mathrm{m}$ and vertically $8233.2 \mu \mathrm{m}$ from Dektak image of Raw Wafer. Again from the above Figure 2, we observed that the surface of the wafer was in pyramid shape and the height of one pyramid was found $15222 \AA$.

Again from the Dektak image and from Figure 3, it was seen that after doping the height of pyramid shape was $55654.1 \AA$. So, the wafer surface is now able to absorb more sunlight since the pyramid height is now increased by a large amount. Some characterization tests were carried out after preparing a complete solar cell and these tests had been shown how efficient the solar cell was. The LIV tester, major characterization equipment, was used to find out the efficiency of the solar cells. These data were required to calculate the efficiency of a solar cell from the ratio of maximum output power to the input power.

The efficiency $(\eta)$ which is the key factor considered in any photovoltaic solar cell can be calculated from the ratio of maximum output power to the input power by using Equation (1).

$$
\eta=\frac{V_{\text {oc. }} I_{S c . F F}}{P_{\text {in }}}
$$

Where, $P_{\max }=V_{o c} \times I_{s c} \times F F$ and $\mathrm{P}_{\text {in }}$ is the input power (Total Solar Irradiance) [19]

Figure 6 shows the measured LIV data at Solar Cell Fabrication Laboratory (SCFL). The characterization of V-I curve and the efficiency of the fabricated solar cell were obtained from the measured LIV data. From Figure 6, it was noted that the efficiency of the produced solar cells were approximately $3.3 \%$ at the present condition. Optimizing the 
better textured silicon wafers as well as the air quality, water quality and other chemicals, it may be possible to raise the efficiency of the solar cell more than the present condition in our country.

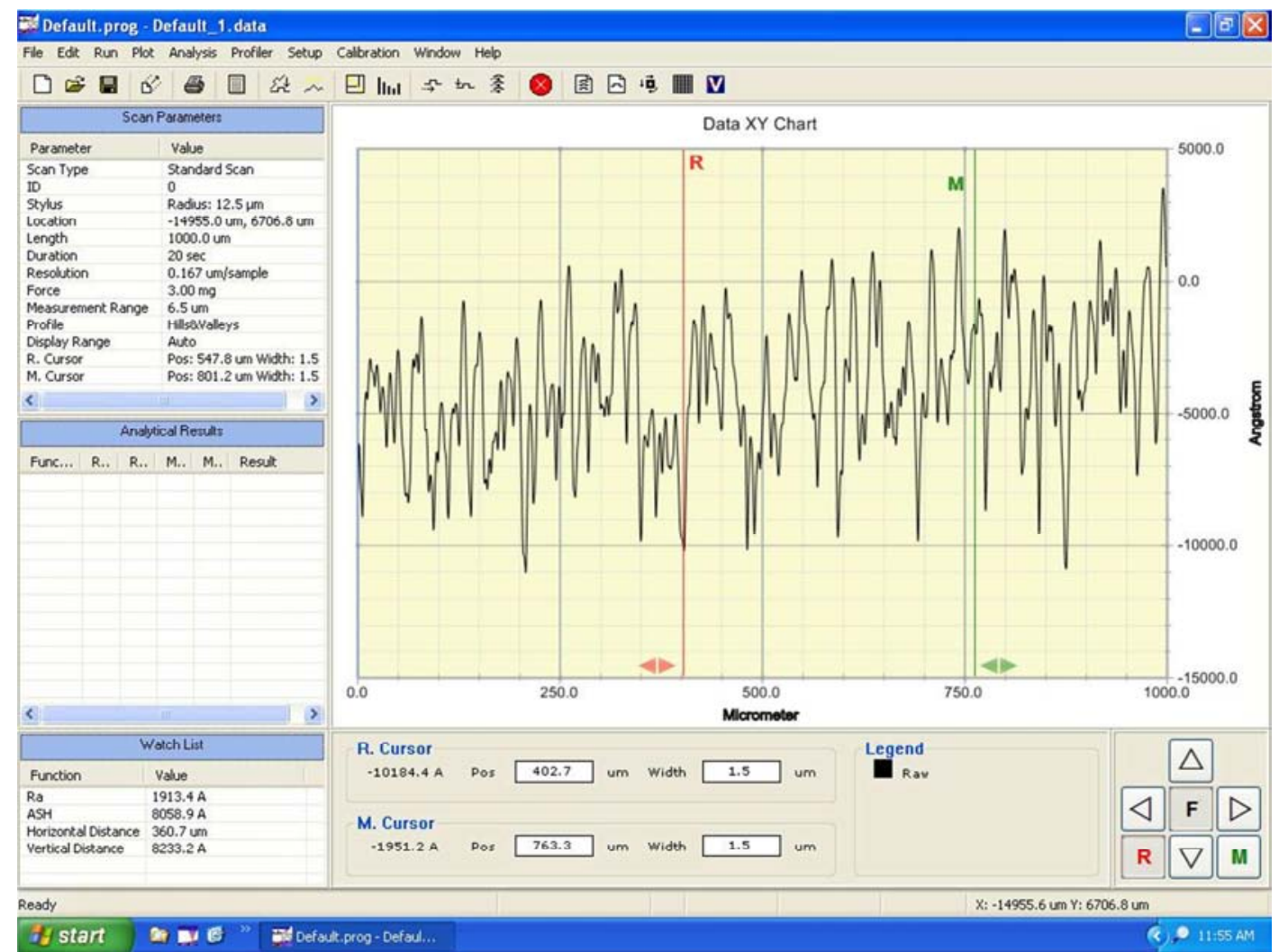

Figure 1. Dektak image of raw wafer.

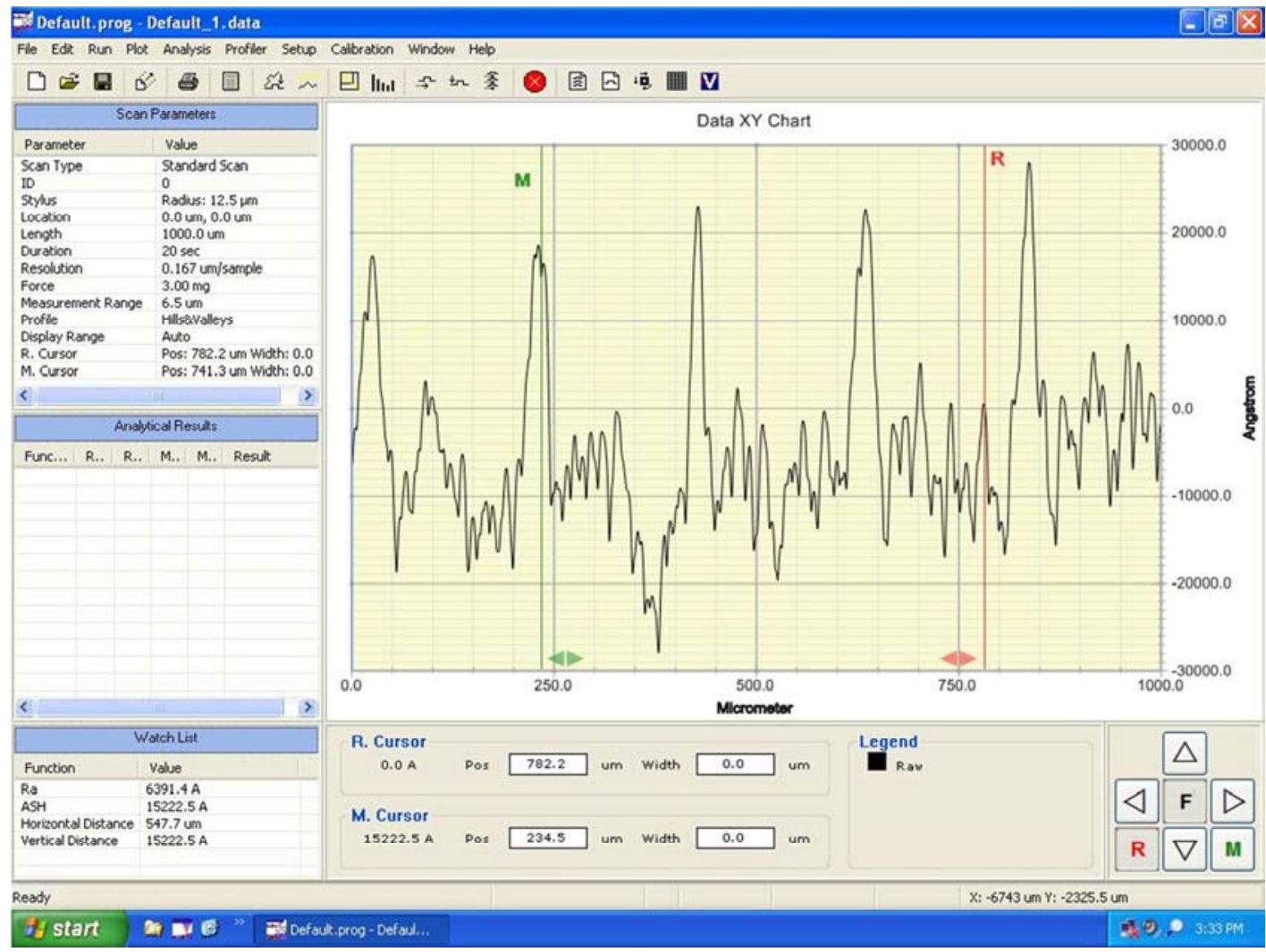

Figure 2. Dektak image of textured wafer 


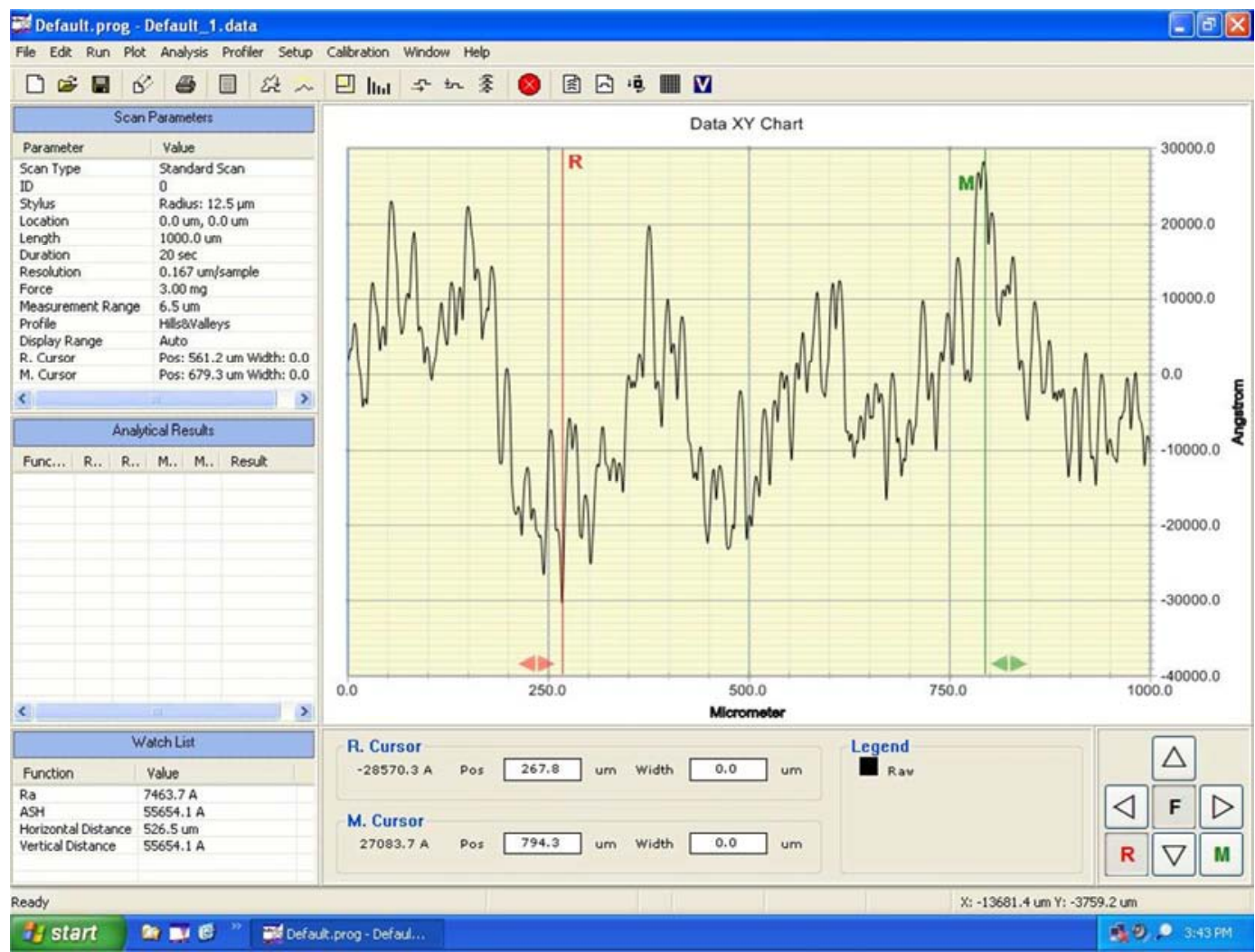

Figure 3. Dektak image of doped wafer.

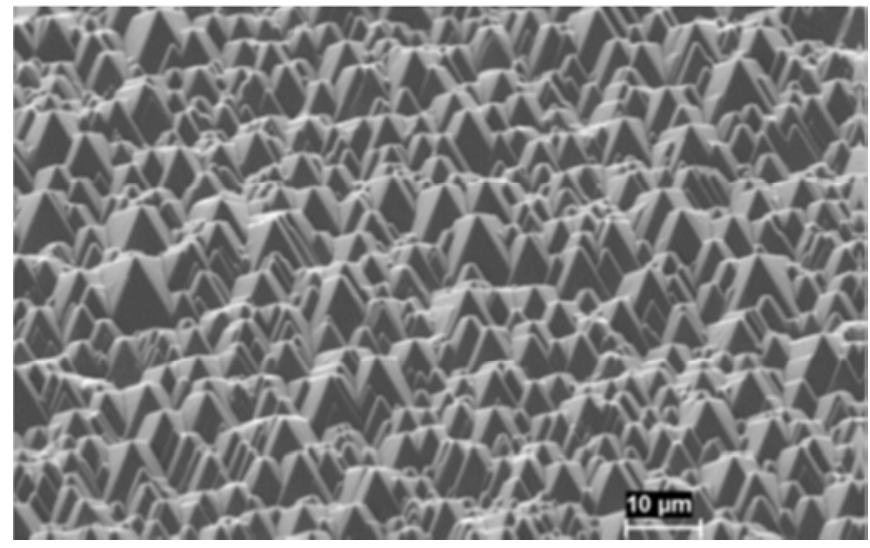

Figure 4. Side view of textured surface [17].

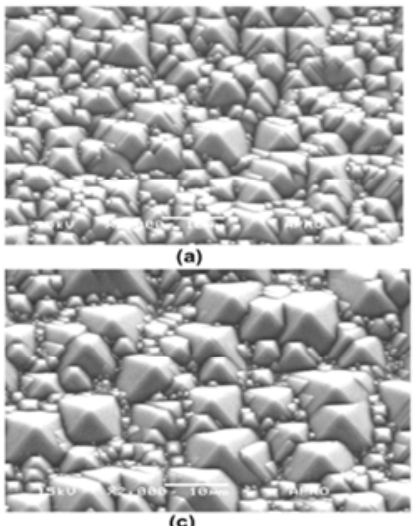

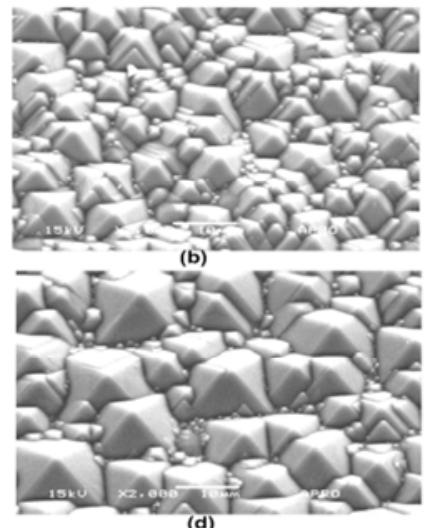

(d)

Figure 5. SEM Micrograph of textured silicon wafer for (a) $25 \mathrm{~min}$ (b) $30 \mathrm{~min}$ (c) $35 \mathrm{~min}$ (d) $40 \mathrm{~min}$ [18]. 


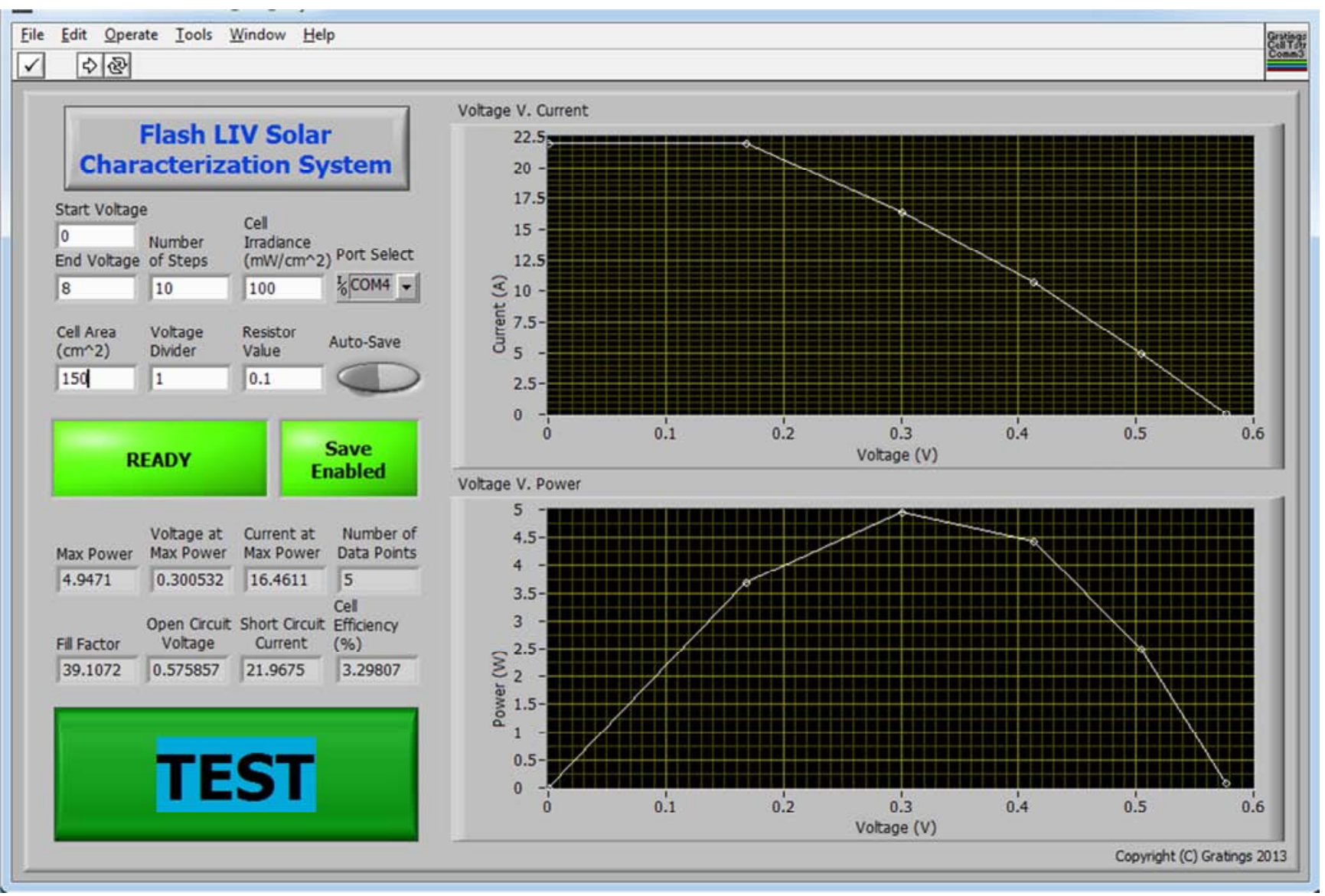

Figure 6. Measured LIV data at SCFL.

\section{Conclusion}

The Si-based solar cell was fabricated using p-type silicon wafers due to their photovoltaic and optical properties. In this fabrication process we have used $\mathrm{POCl}_{3}, \mathrm{NaOH}$, Aluminium and Silver paste chemicals. For instance, texturing process, optimum flow rate for $\mathrm{POCl}_{3}$ and fixing the different temperature zones of RTA process have been achieved properly which can significantly enhance the efficiency of solar cell. Moreover, doping concentrations have to be further optimized and carefully characterized to get more improvement. The efficiency of the fabricated solar cell was $3.3 \%$. As we have huge sunlight, we can convert this sunlight to electricity with the help of a solar cell as we have developed. In the near future, optimizing all the challenges the laboratory in Bangladesh Atomic Energy Commission (BAEC) will play a pioneer role in developing as well as promoting solar cell fabrication technology in the country.

\section{Acknowledgements}

The authors are highly grateful to all the staffs of the Institute of Electronics, Atomic Energy Research Establishment, Savar, Dhaka, Bangladesh for providing the necessary facilities required for this research.

\section{References}

[1] Yadav, A. and Kumar, P. (2015) Enhancement in Efficiency of PV Cell through P\&O Algorithm. International Journal for Technological Research in Engineering, 2, 2642-2644.

[2] M. Meister, Charge generation and recombination in hybrid organic/inorganic solar cells, Johannes Gutenberg-University of Mainz, Germany: Doctoral dissertation (2013). Retrived from http://pubman.mpdl.mpg.de/pubman/item/escidoc:1739298:4/ component/escidoc:1850189/Thesis

[3] Photovoltaics Report". Fraunhofer ISE. 28 July 2014. Archived from the original (PDF) on 31 August 2014. Retrieved 31 August 2014.

[4] Wu, Y. and Gorder, P. F. (2014) Nature Communications. Published on 3 October 2014.

[5] Bagher, A. M., Vahid, M. M. A. and Mohsen, M. (2015) Types of Solar Cells and Application. American Journal of Op-tics and Photonics, 3, 94-113.

[6] Fraunhofer Photovoltaic Report"

https://www.ise.fraunhofer.de/content/dam/ise/de/documents/p ublications/studies/Photovoltaics-Report.pdf

[7] H. Kidowaki, T. Oku, T. Akiyama \& A. Suzuki, "Fabrication and Characterization of CuO-based Solar Cells", Journal of Materials Science Research, 1(1), 138-143 (2012). doi:10.5539/jmsr.v1n1p138 
[8] J. J. Wysocki \& P. Rappaport, "Effect of Temperature on Photovoltaic Solar Energy Conversion”, Journal of Applied Physics, 31,571-578 (1960). http://dx.doi.org/10.1063/1.1735630

[9] G. Chem \& I. Kashkoush, "Effect of pre-cleaning on Texturization of c-Si wafers in a KOH/IPA Mixture", ECS Transaction, 25(15), 3-10 (2010). http://ecst.ecsdl.org/content/25/15/3.full.pdf

[10] D. Munoz, P. Carreras, D. Ibarz, S. M. Nicolas, C. Voz, J. M. Asensi \& J. Bertomeu, "Optimization of $\mathrm{KOH}$ etching process to obtain textured substrates suitable for heterojunction solar cells fabricated by HWCVD”, Thin Solid Films, 517(12), 3578-3580 (2008).

[11] Badawy, W. A. (2015) A Review on Solar Cells from Si-Single Crystals to Porous Materials and Quantum Dots. Journal of Advanced Research, 6, 123-132.

http://dx.doi.org/10.1016/j.jare.2013.10.001

[12] Ahn, N., Son, D.-Y., Jang, I.-H., Kang, S. M., Choi, M. and Park, N.-G.(2015) Highly Reproducible Perovskite Solar Cells with Average Efficiency of $18.3 \%$ and Best Efficiency of $19.7 \%$ Fabricated Via Lewis Base Adduct of Lead(II)Iodide. Journal of the American Chemical Society, 137,86968699. http://dx.doi.org/10.1021/jacs.5b04930

[13] Shi, D., Zeng, Y. and Shen, W. (2015) Pervoskite/c-Si Tandem Solar Cell with Inverted Nano pyramids: Realizing High Efficiency by Controllable Light Trapping. Scientific Reports, 5, Article No. 16504.
[14] Mohanta, P. R., Patel, J., Bhuva, J. and Gandhi, M. (2015). A Review on Solar Photovoltaic and Roof Top Application of It. International Journal of Advanced Research in Science, Engineering and Technology, 2, 2394-2444

[15] Srinivas, B., Balaji, S., Nagendra Babu, M. and Reddy, Y. S. (2015) Review on Present and Advance Materials for Solar Cells. International Journal of Engineering Research-Online, 3, 178-182.

[16] Maehlum, M. A. (2015) Energy Informative The Homeowner's Guide To Solar Panels, Best Thin Film Solar Panels - Amorphous, Cadmium Telluride or CIGS? Last updated 6 April 2015.

[17] M. Al-Amin1 \& A. Assi, "Efficiency improvement of crystalline silicon solar cells", Materials and processes for energy: communicating current research and technological developments, 22-33 (2013).

[18] S. M. Iftiquar, Y. Lee, M. Ju, N. Balaji, S. K. Dhungel \& J. Yi, "Fabrication of Crystalline Silicon Solar Cell with Emitter Diffusion, SiNx Surface Passivation and Screen Printing of Electrode", Photodiodes- From Fundamentals to Application, Chapter 3, 105-132 (2012).http://dx.doi.org/10.5772/51065

[19] M. L. Marcelo, An analysis of the Fabrication, Characterization and Application of Academically developed Solar Cells, Faculty of Enigeering, Pontifical CatholicUniversity of Rio Grande do Sul, Brazil: B.Sc. thesis (2014). Retrived from http://www.inf.pucrs.br/ moraes/my_pubs/tcc/tcc_marcelo_li nk.pdf 